\title{
Strategies for Organizational Intervention to Develop a World-Class Company
}

\author{
José G. Vargas-Hernández ${ }^{*}$, M. I. Julián Adolfo Adame Miranda ${ }^{2}$ \\ ${ }^{1}$ University Center for Economic and Managerial Sciences, University of Guadalajara, Jalisco, 45100, MÉXICO \\ ${ }^{2}$ Doctorado en Administración y Ciencias Organizacionales, Universidad LaSalle, MÉXICO \\ *Corresponding Contact: \\ Email: josevargas@cucea.udg.mx
}

\begin{abstract}
The aim of this paper is to present the case of organizational intervention in the monopolistic state-owned company, the Federal Electricity Commission (CFE). Here are presented the diagnosis of the CFE, the strategies in place to make it a world-class company and the results obtained. The trial follows the methodology of Organizational Intervention (Vargas-Hernandez, 2014); i.e. in three main areas that constitute the components of the classic strategic model of organizations (Vargas-Hernandez, p.44): the organizational structure axis, the axis of processes / technologies and mainly the third axis corresponding human behavior.

[El objetivo de este trabajo es presentar el caso de intervención organizacional en la empresa monopólica del Estado, la Comisión Federal de Electricidad (CFE). Se presentan el diagnóstico de la CFE, las estrategias establecidas para convertirla en una empresa de clase mundial y los resultados obtenidos. El ensayo sigue la metodología de Intervención Organizacional (Vargas-Hernández, 2014); es decir, en tres grandes ejes que constituyen, los componentes del modelo estratégico clásico de las organizaciones (Vargas-Hernández, p. 44): el eje de estructura organizacional, el eje de los procesos/tecnologías y principalmente, el tercer eje que corresponde al comportamiento humano.]
\end{abstract}

Key Words: World Class Company, strategy, organizational intervention

[Empresa de clase mundial, estrategia, intervención organizacional]

\section{INTRODUCTION}

The CFE was created on August 14, 1937 (Reséndiz-Nunez, 1994, p.20) and it was issued in 1939 the Electricity Industry Act. Significantly, the statement by President Abelardo L. Rodríguez expressed that within the purpose of nationalizing the generation and distribution of electricity, the law of 29 December 1933 authorizing the Federal Executive to form a Federal Electricity Commission. It was then explicit intention of the government of Mexico to nationalize an activity that was entirely by individuals under the system of concessions granted by the State. 
From this moment the infrastructure works for power plants and transmission lines, especially in those places where it did not represent a business for private companies still operating in the country began. Some of them were over 20 years in which the installed generation capacity increased on average only $1 \%$, insufficient growth to meet the needs of the country's industrialization and the needs of domestic consumption, especially in remote areas of large population centers.

Thus, in September 1960 President Adolfo Lopez Mateos stated that the provision of public services generation, transformation and supply of electricity, either by governmental institutions, bodies of the nation, through which is always present, as the last commander of all its management, the Mexican people (Resendiz-Nunez, 1994, p.27).

Technically two important events for the country, interconnection of power systems and the unification of the generation frequency $60 \mathrm{~Hz}$ were given. At work at the time of nationalization were two Unions which merged in November 1972 giving rise to the current CFE Union, the Trade Union of Electrical Workers of the Mexican Republic (SUTERM). This union currently holds the title of the Collective Bargaining Agreement. Financially the rate increase that had remained static for 20 years in order to achieve a balance between the average price and the average cost (Electricidad, 1977, p.72) began.

After nationalization came a stage of development of the company and the electricity sector in general. The structure was maintained with a single CEO, who basically was responsible for the financial and political functions and deputy general manager who was responsible for the technical part. The latter was changed in the decade of the 70 when were created three directions that depended on the general direction that took care of the important technical processes, one of them the whole operation, the second part of the construction and the third one for administration and finance. In the part of processes and technology it grew with the support of foreign enterprises (EDF of France mainly) forming unified own procedures for the whole country with the support of Testing Laboratory (LAPEM) of CFE.

In the working part the training area was formed for engineers and field staff this being strength of the company. However, as many unions in the country, the rise remained seniority rather than by ability.

\section{Organizational Structure}

After the nationalization of the electricity industry, the CFE proceeded to the settlement of all private companies that as businesses were providing the service in different parts of the country. Similarly, unification of trade unions began until the formation of SUTERM (Convention Unity Pact, which signed the National Union of Electrical, Similar and Allied of Mexican Republic and Electrical Workers of the Mexican Republic on November 20 1972).

Although it remained Luz y Fuerza, with the Mexican Electricians Union, as a parastatal or state owned enterprise, it was governed by its own strategies, very different from CFE and its fields of action (Agreement between the Mexican Electricians Union and SUTERM) were defined. In 20 years it grew the corporate structure to have a director and a deputy director to have five directors, deputy directors just under 20 and over 60 managers. Regionally from step of having six managers who controlled all processes of the value chain, generation, transmission, processing and distribution, to have a manager for each process growing to 25. At work it had more than 100 thousand workers. The CFE became a state monopoly where there was no concept of client and much less policy attention to them. 
Each foreign area became a preserved power and its manager worked independently of the general policies of the company, operating as feudal lords. Productivity was very low compared to other similar companies in the world.

At central level and due to system growth level was a restructuring that split the company into two; on the one hand the Director General (Cervantes del Rio) in charge of finance and administration and a new sub direction, the construction (Carrion Hernandez) was growing much due to the expansion of the power plant and increased transmission lines. At this time all investment in infrastructure of CFE was $100 \%$ with tax money. The other important part that the company split was the Sub Direction of Operation (Escofet Artigas) that concentrated the important processes of the value chain: generation, transmission, distribution and control.

This policy of growth of the company, both in structures and in staff, with state resources became untenable and during the administration of President Salinas de Gortari (1992) intervention to improve business productivity began with the signing of Productivity Agreement concluded between the Federal Electricity Commission and the Sole Union of Electrical Workers of the Mexican Republic (Resendiz-Nunez, 1994, p.646).

\section{Problems in the structure of the company.}

The problems in the structure of the company can be summarized as follows:

- Very large and bureaucratic organization

- Lack of unionized staff productivity

- $\quad$ Lack of competitiveness

- Lack of corporate quality manuals

- Lack of financial literacy.

- Lack of knowledge of organizational culture.

- Absence of a Strategic Plan

- Lack of management indicators

- Lack of commitments processes to meet goals

\section{Human behavior}

Until 1992 there was a real commitment of workers with their productivity mainly due to lack of knowledge of the goals of the company and especially to ignore the value that their work contributed to the company. Each contract review was asking for more benefits for nothing. The rise of staff was by seniority so there was no concern for preparing, by paying more, no matter if were skills and knowledge to get a promotion, it had sufficed to wait for immediate superior vacated his post and that. The union was engaged in protecting workers regardless of whether they were bad and to negotiate annual increases in salary and benefits.

The training was not due to a profile established and this knowledge was provided by the most experienced or in best cases, regionally it was beginning to provide formal training.

\section{The main problems in human behavior}

These problems are summarized in the following points:

- Lack of motivation

- Lack of commitment to the goals of the company

- Teamwork 


\section{Process / Technology}

The value chain of electricity production is similar, if not the same in all countries; generate primary energy, which can be falling water in a hydroelectric, burning fossil fuels, fuel oil and diesel or gas and nuclear energy; transmit the energy generated by transmission lines, substations and finally transform distributed in populations through distribution lines. Technologically they used in all countries the same equipment manufacturing transnational corporations, in some cases established in countries like Mexico.

National integration in generation was very low, approximately $30 \%$. By transmission was about $50 \%$ and distribution was about $90 \%$ (Reséndiz-Nunez, p.220-250) A first intervention that took place in CFE was the program of import substitution had some results, especially in low-technology equipment. This intervention failed when Mexico entered to the General Agreement of Trade and Tariffs (GATT). Thus, Mexico entered to the globalized world and support to the domestic industry was completed. To operate the electrical system followed models developed rapidly in the US that was replaced by models developed by the Instituto de Investigaciones Eléctricas (Institute of Electrical Research).

\section{The technological problems of the sector}

These technological problems are summarized in the following points:

- High losses in transmission and distribution of energy

- Improve the efficiency of generation

- There was no market power for lack of competition

- Financial systems not networked

- Little awareness of sustainability

- $\quad$ Lack of quality and competitiveness models

\section{ORGANIZATIONAL INTERVENTIONS}

There were two key stages of organizational intervention. The first was during the administrations of Presidents Carlos Salinas de Gortari and Ernesto Zedillo, being Directors of CFE the Engineers Guillermo Guerrero Villalobos and Alfredo Elias and the second was during the administration of President Vicente Fox, while still CEO of CFE Engineer Alfredo Elias.

\section{First stage}

- Strategic plan. A high-level group headed by the Director General to develop the first strategic plan of the company was formed. It is noteworthy that all it had CFE (and still has, is a program of works and installations (POISE) with a horizon of 10 years.

- Total Quality Program. The background to the establishment of the Program was the experience in the implementation of the program of Quality Assurance Laguna Verde and the publication of a presidential decree in the Official Gazette instructing entities and agencies of the Federal Government to establish Total Quality programs. So it was introduced the Total Quality Program to Direction of CFE. Given the ambitious nature of the program and the time required for implantation, it was asked to be divided into stages and the first one was, certify the substantive processes of the company in the ISO9000 (CT-9IMNC, Norma CT9-IMNC9000, 2004) standard.

- Convention on productivity with the Union and new collective bargaining agreement. This intervention is probably the most important of the first stage since the administration of Guillermo Guerrero a process of convincing the Union took shape, initiated during the leadership of Fernando Hiriart, to sign the agreement productivity containing among 
other things the ascent by capacity rather than seniority, productivity award for teamwork, prize money that should leave from the savings achieved in each workplace. To develop this program it was formed an internal working team and was advised from the French company Electricity of France (EDF). This intervention was carried out by Transcendent Transformation program to $100 \%$ of staff throughout the country.

- Establishment of the energy market. This intervention was instrumental in restructuring the organization of the company where were established in all the productive areas in Strategic Business Units (SBU) and the areas of administrative and technical support in Strategic Areas Cost (UEC). They were defined for each production area its products, selling prices were set to deliver the next process of the value chain. The domestic market handled it the system control area setting transfer prices for energy.

- Creation of the Environmental Protection Administration. The creation of this management (Reséndiz-Nunez, p.168) was instrumental in starting the program for sustainable development of CFE, environmental, social and economic. CFE was the first public company to obtain resources from carbon bonds, according to the Kyoto protocol.

- Creation of internal Quality Award. This intervention was instrumental in the creation and implementation of a single model of quality implanted in $100 \%$ of the SBU and the UEC. The base model was the National Quality Award (PNC), created by the President of Mexico to reward public and private companies. With the same methodology PNC Quality initiated the Award CFE that was delivered annually to the best areas of business processes. The award was delivered at the annual quality CFE meeting, which brought together more than a thousand workers throughout the country. At this meeting it was given a great importance to the development of organizational culture of each region, became an exhibition in which the technical achievements and artistic culture such as painting, crafts and music of each region had.

- Implementation of SAP. This intervention meant a radical change in the way of exercise and controls the budget. One management charge of implementing and operating the system throughout the country and most importantly, the adequacy of SAP to the structure of the company and not the reverse, as the German company, which owns the license was formed was used to make.

\section{Second stage}

- Company certification under ISO 9000, ISO14000 and OSHAS18000 standards. In this intervention, not only was achieved a certification in the quality standard ISO9000 but also in the environmental standard ISO14000 (CT-9IMNC, Norma CT9-IMNC14000, 2004) and the safety standard OSHAS18000 (CT-9-IMNC, 2008), all three under one management model.

- Establishment of quality and competitiveness model. This model was the first model of evolution of quality to which the concept of competitiveness is also added following the evolution of the PNC.

- Promotion for obtaining National Quality Award. From top management, support and encouragement was given to areas that had won the national quality award, they were to compete for the PNC. Similarly, it was promoted to the winners of the PNC who were to compete for the Ibero-American Quality Award, an award presented annually by the King of Spain during the meeting of heads of state of countries of Spanish and Portuguese speaking countries. 
- Creation of the Corporate University CFE. Leading companies in the world have their own university to specialized workers preparation, often in partnership with wellestablished Universities. This corporate university obtained the registration of the Ministry of Public Education (SEP).

- Policy World Class Company. The last intervention was the establishment of the policy of turning the CFE world class company with 8 strategies that virtually all interventions summary of the two stages.

\section{STRATEGIES}

Global space operations. Harnessing the global economic environment in terms of market, capital, interest rates, labor costs, taxes, regulations, available infrastructure, etc. The operations of the company have no border limits, market and resources are global.

Global competitiveness. The world-class companies seek to maintain their lead over the competition, which means operating at optimum levels of productivity and efficiency: Continuous benchmarking, use of statistical tools for process optimization (six sigma), total quality model, listen to the customer opinion and measurement and evaluation of all processes.

Optimal use of resources: Global optimization of operations, global collaboration with suppliers, parts standardization and reduction, flexible manufacturing and services, use of cost systems based on activity / process.

Global administration. The administration in these businesses adds value, it is a process that contributes to decision-making, to maintain and improve productivity and efficiency.

Global strategic planning. Planning must be highly effective; it must take into account the environment and the long term. It should be clear that the future is built day by day: Vision and global mission, minimum response times to changes in the environment, diagnosis of global opportunities, global strategies, and a system of global intelligence and use the Balanced Scorecard (BSC).

Global corporate culture. Deep respect for ethical values, myths and rituals of the population, people are keys to the organization: Constant training at all levels, policies of respect and recognition to individuals, selection of highly qualified personnel, with global culture and knowledge of several languages.

Research and development. The mainstay of the company should be innovation and creativity of staff.

Global learning. Knowledge must be the cornerstone of growth and continuous improvement. It must operate a system of knowledge management.

\section{RESOURCES}

The CFE has within its organization the Testing Laboratory to Equipment and Materials (LAPEM) management that depended on the Technical Sub Direction responsible for ensuring the quality of purchased products and has traditionally been a leader in the country in the field of metrology, measuring, testing and quality. This area was responsible for the intervention in the implementation of ISO standards, the development of models of quality and competitiveness, evaluation for internal quality award and the establishment of strategies world-class company. No was hired any advice or consultancy to achieve this. The costs that were incurred were payment of evaluator's agencies for granting certification quality, environmental and safety standards. 
To design of the productivity agreement was counted with the assistance of the French company EDF. For the implementation of SAP the costs incurred were the preparation of all persons who would be responsible for system operation throughout the country.

\section{ANALYSIS OF RESULTS}

- Ascent by seniority was removed.

- The company was restructured by creating the Strategic Business Units and Costs.

- Internal energy market was established.

- Boards were formed in each substantive process.

- Decreased absenteeism.

- Productivity agreement was included in the Collective Bargaining Agreement

- Teamwork rewarding group productivity by savings achieved.

- CFE University was founded with 14 offices nationwide.

- Lowered the number of workers from over a hundred thousand to only 80 thousand.

- Indicator system was established to qualify the Strategic Units.

- Business, highlighting the decline of the number of workers per field crew, efficiency in the generation, lower transmission losses and distribution, downtime per user, service time for connection and increasing the number of services per worker.

- $\quad$ All UEN and UEC were certified in ISO9000 standard.

- Management model for quality and competitiveness was established in all the UEN.

- More than 15 National Quality Awards were obtained

- Three Iberoamerican Quality Awards were obtained.

- A policy of World Class Company was established.

- Financial system with the implementation of SAP was unified.

- The first sale of carbon credits from a State enterprise was achieved

\section{ConcLusions}

All CFE management indicators improved substantially. Everything invested in organizational intervention was truly recovered at CFE and stood as a world-class company.

\section{REFERENCES}

CT-9IMNC. (2004). NORMA CT9-IMNC14000. MÉXICO, D.F.: IMNC.

CT-9-IMNC. (2008). Norma CT9-IMnc18000. México, D.F.: IMNC.

CT-9IMNC. (2008). Norma CT9-IMNC9000. México, D.F.: IMNC.

Electricidad, C. F. (1977). Evolución del sector eléctrico en México. CFE.

IMNC. (2 de enero de 2008). Sistemas de Gestión de la Calidad. México, Distrito Federal, México: IMNC.

Reséndiz-Núñez, D. (1994). El sector eléctrico de México. México, D.F.: Fondo de Cultura Económica.

Vargas-Hernández, J. (2014). Gestión Estratégica de Organizaciones. Buenos Aires: elaleph. 
Publish Online and Print Version Both

ISSN Online: 2307-9592 